\title{
Project Managers Vs Operations Managers: A comparison based on the style of leadership
}

\author{
Hadi Minavand ${ }^{1}$, Vahid Minaei ${ }^{2}$, \\ Seyed Ehsan Mokhtari ${ }^{2}$, Nasrin Izadian ${ }^{2}$, Atefeh Jamshidian ${ }^{2}$ \\ ${ }^{1 \& 2}$ International Business School / Universiti Teknologi Malaysia (UTM)
}

\begin{abstract}
Within a century after the emergence of the initial theories in leadership area, several theories have tried to explain the different styles of leadership and the extent to which leaders' styles can affect the overall success of the teams or the organizations being led by them. Regardless of the different ways in which these theories explain and address the styles of leadership, two concepts of 'task' and 'individual' are focused by most of them. Leaders, depending on their personal traits, attitudes, and situational considerations may show different levels of concern for tasks and individuals. Also, the environment in which a leader operates may affect the leader's concern for tasks or individuals. Project environments, regarding the temporary nature of projectbased activities, basically differ from operational environments in several aspects. Consequently, leadership in project environments may require a different style in comparison with operational environments. The current study has applied 'concern for tasks' and 'concern for individuals' as two dependent variables to make a comparison between project managers and operations managers based on the style of leadership. An online survey in a global context helped us to collect data from 159 project managers and 171 operations managers. The respondents were from different countries and various disciplines. The collected data were analyzed in SPSS using 'independent sample t-test'. The results of the analysis revealed that project managers in general show a balanced concern for tasks and individuals, whereas operations managers have a high concern for tasks and a lower concern for individuals.

Keywords - Project manager, Operations manager, Leadership style, Tasks, Individuals
\end{abstract}

\section{Introduction}

Within the recent decades, academicians and researchers have suggested several definitions to describe the concept of 'leadership'; but in general, leadership is defined as "the process in which an individual exerts influence upon activities of an organization or a group of people in order to motivate and conduct them toward a common goal" (Northouse , 2010) [1]. According to this definition a leader has the highest influence over the strategy of an organization and long-term objectives are normally set by the leader. But leaders, depending on their personal traits, attitudes, and the environment in which they operate, may use different ways to exert the mentioned influences. "The way in which the functions of leadership are carried out, or the manner that a manager chooses to behave towards employee" is defined as the style of leadership (Mullins, 2000)[2]. Leadership style is a behaviorally oriented approach to understand the concept of leadership. Subordinates, normally look at their leaders' behavior as their 'style' of leadership. Consequently, 'behavior approach' and 'style approach' could be used interchangeably (Bryman, 1992) [3]. Behavioral theory introduces two styles of task-orientation and individual-orientation (also known as relationship-orientation) as the two extremes of a leader's behavior (Bolden et al, 2003)[4].

However, Staehle (1999)[5] believes that leadership is an empirical attempt (to influence and conduct others) which is sometimes seriously affected by the situation. Krumm (2001)[6] suggests that effective leaders may apply both orientations (task-orientation and individual-orientation) depending on the situation. Yukl (2002)[7] argues that two aspects of situation determine the extent to which leader behaviors influences on employees' performance: employee characteristics and environmental characteristics. One of the most influential environmental characteristics according to him is the nature of the work group. Bryman (1992)[3] believes that in terms of environmental characteristics, the efficiency of a leader's behavior directly depends on the task's nature.

The above arguments reveal that the styles chosen by leaders (or managers) could be highly affected by the environment in which they operate. For instance, project environments differ from operational environments in the nature of tasks and work groups; consequently, a project manager is expected to use a leadership style different from an operations manager. The current research is designed to examine this idea and make a comparison between the leadership styles of project managers and operations managers. 


\section{LITERATURE REVIEW}

In this part, first of all two concepts of leadership and management are described and compared. Then, the styles of leadership will be assessed from the viewpoint of behavioral theory. At the end, two major types of management will be described and the studies which have compared the leadership styles of different groups of managers will be reviewed.

\section{II.I Leadership Vs MANAgement}

Distinguishing leadership from management has been one of the most common arguments amongst academicians in recent decades; however there are increasing evidences which illustrate that this distinction may be harmful and misleading. Zaleznik (1977)[8] argues that managers are normally reactive, and in spite of their willing to work with others to solve problems, they do it with a minimum level of emotional involvement. Leaders on the other hand, are more emotionally involved and tend to generate ideas proactively instead of reacting to the ideas generated by others. He also believes that leaders try to change other's attitudes, whereas managers are satisfied with only changing their behavior. Nanus (1985) [9], suggests that managers could be identified as individuals who "do things right" whereas leaders are those who do "the right thing".

The main point of these distinctions is a tendency towards change. This concept is clearly reflected in John Kotter (1990)[10]'s study. He argues that "management is about coping with complexity" whilst "leadership, by contrast, is about coping with change". He also states that good management provides a degree of consistency and order for an organization whereas leadership focuses on dynamic change of the organization. The distinction of management from leadership as described by Kotter and others clearly represents a shift from an inflexible and bureaucratic approach which is called 'management' to a more dynamic, flexible, and strategic approach which is classified as 'leadership'.

In spite of the popularity of the distinction between leadership and management, there is still some doubt about the extent to which they are really separate in practice. Gosling and Mintzberg (2003) [11] believe that "Most of us have become so enamored of leadership that management has been pushed into the background. Nobody aspires to be a good manager anymore; everybody wants to be a great leader. But the separation of management from leadership is dangerous. Just as management without leadership encourages an uninspired style, which deadens activities, leadership without management encourages a disconnected style, which promotes hubris. And we all know the destructive power of hubris in organizations."

As a whole, despite the fact that making a distinction between management and leadership can be useful in attracting attention to the motivator and strategic actions needed during courses of change, the bipolar perspective of managers and leaders as two completely different groups of people can be misleading and actually harmful in practice. According to Bolden (2004) [12], if we believe that managers and leaders are different people, it could be concluded that (a) due to any change in circumstances, the management team should be changed necessarily. (b) It is not possible for leaders to become managers and vice versa. He believes that such an idea about leadership and management is highly limited and severely underestimates the capabilities of people in both roles. However, this is not to say that all people are fitted equally to all aspects of management and leadership; also it does not mean that there is a unique profile which is suitable for all situations; but in order to achieve the maximum effectiveness employers should seek to hire and develop 'leader-managers' who have enough capability to adopt their roles in its most holistic form.

Based on the above-mentioned arguments and according to Mintzberg (2004)[13], the words 'leadership' and 'management' or 'leader' and 'manager' will be used interchangeably throughout this study and 'leadership style of managers' will be addressed and discussed as the basis of current study.

\section{II.II BEHAVIORAL THEORY AND THE CONCEPTS OF TASK AND INDIVIDUAL}

Behavioral theory emerged in the middle of the $20^{\text {th }}$ century in response to the criticism against trait theory. Unlike trait theory which posited that leaders are born not made behavior theory claimed that leadership could be learnt by training. The main focus of this theory was on leaders' behaviors instead of their personal traits. In fact behavior theory (also known as style theory) intended to concentrate on different styles of leadership and explore those parts of a leader's behavior that result in organizational success (Bolden et al, 2003) [4]. Anyway, this theory made a revolution in approaches to leadership and provided a basis for following theories. Further studies based on behavioral theory identified two types of leaders' behaviors ; one emphasizing on the enhancement of job performance procedures and techniques as the key factor of success and the other emphasizing on achieving objectives through employee motivation .

In other words, behavioral theory of leadership introduces individual-orientation and task-orientation as the two major styles of leaders/managers. This theory considers above-mentioned styles as two extremes of leaders' behavior whereas some leaders may prefer a combination of both styles (Bolden et al, 2003) [4]. 
The primary concern of task-oriented leaders, is achieving defined targets of their business. Northouse (2011) [14] believes that task-oriented leaders encourage their employees to achieve their objectives by giving them exact definitions about their roles, establishing objectives and criteria of evaluation, specifying directions and instructions, setting time schedules, and determining the ways by which goals could be achieved. He also argues that task-oriented leaders focus on all activities related to the work such as planning, scheduling and controlling. Yukl et al (2009)[15] take into account activities such as assigning individuals' tasks, explaining details of their responsibilities, and illustrating expectations as the main behaviors of task-oriented leaders.

On the other hand, the main concern of individual-oriented leaders is mostly focused on building and developing interpersonal relationships. Northouse (2010) [14] argues that it is very important to them to help employees to feel comfortable in the workplace. This group of leaders normally helps employees to develop their careers. They provide all job-related information to enhance employees and allow them enough degree of autonomy in their work. They are also very grateful to their employees. Yukl (2006) [16] believes that the most important behaviors of individual-oriented leaders could be categorized into three sorts of behaviors including "supporting", "developing", and "recognizing" behaviors. Supporting behaviors according to him include demonstrating concern, acceptance, and confidence for the feelings and needs of employees. He also defined developing behaviors as all activities which are done by a leader to enhance their inexperienced colleagues and subordinates. Recognizing behaviors refers to those activities that leaders carry out to appreciate others cause of their effective performances, considerable achievements, or good contributions to organizational objectives.

\section{II.III TYPES OF MANAGEMENT AND THE STYLES OF LEADERSHIP}

'Project' and 'Operations' are normally recognized as the two main phases of any business. The first one is known as a phase in which resources are consumed, whereas in the second one, new resources are generated (Prabhakar, 2008) [17]. In addition, projects are temporary activities with unique outputs, whereas operations are permanent activities with repetitive outputs (PMI, 1996) [18]. These differences between the two phases of a business, result in two separate types of management: project management and operations management. It is predictable that these different types of management require managers with different competencies and styles of leadership.

Pinto et al. (1998) [19] found a relation between the type of management and the styles of leadership introduced by behavioral theory. They claimed that project managers show more concern for people than other managers. Makilouko (2004) [20] argued that relationship-oriented (individual-oriented) managers have better interrelation skills and concluded that they are the best choice to be assigned as project managers specifically in international and multicultural projects. Jacque et al. (2007) [21] conducted a research among a group of MBA students and concluded that those students who are attracted to project management in comparison with other students have a higher concern for individuals. Dulewicz \& Higgs (2005) [22] and Turner et al (2009) [23] focused on leadership competencies and tried to explain and compare leaders' behaviors based on some specific competences. Dulewicz \& Higgs (2005) [22] categorized leadership competencies into three groups of IQ (intellectual), EQ (emotional) and MQ (managerial). Turner et al (2009) [23] used these competences to compare the leadership behaviors of project managers with the managers of functional and operational environments. They found that that project managers score higher than functional managers on conscientiousness, sensitivity, and critical analysis, but they score lower on communication and development competencies.

\section{CONCEPTUAL FRAMEWORK AND HYPOTHESES}

As described in the previous sections, the current study intends to make a comparison between project managers and operations managers (as the two major classes of managers) based on their leadership styles. In other words, it is targeted to find out which group is more task-oriented and which one is more individualoriented. For this purpose, the managers' concern for tasks and concern for individuals were selected as dependent variables and 'type of management' was defined as the independent variable. The following figure illustrates the framework of this study.

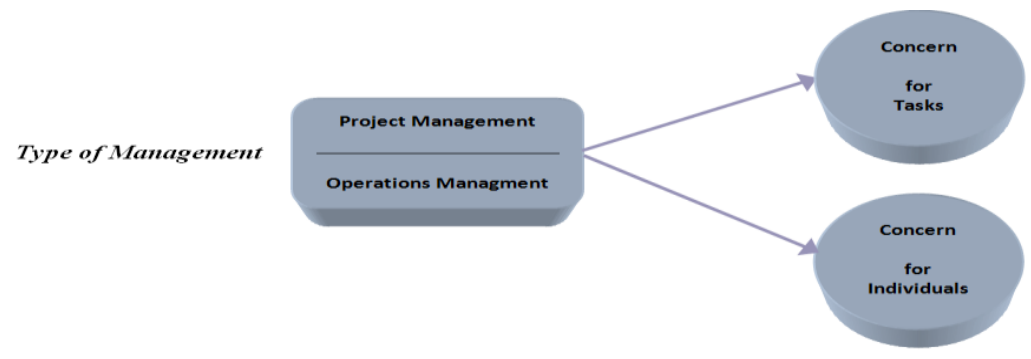

Figure 1 Conceptual framework 
The above framework (Fig.1), led us to propose our hypotheses as follows:

H1: There is a significant difference between project managers and operations managers in 'concern for task'.

H2: There is a significant difference between project managers and operations managers in 'concern for individuals .

\section{METHODOLOGY}

An online survey was selected as the method of data collection. The survey was conducted in a global context and the middle managers of organizations, regardless of the industry, discipline, or nationality to which they belonged were focused as the target population of current study.

A questionnaire including two parts was designed and applied as the research instrument. The first part was designed to assess the respondents' demographic data including age, gender, the years of working experience. In addition, at the end of this part, the respondents were asked to determine the type of their managerial positions depending on the context in which they operate. In other words, they were requested to state whether they manage a project team or they are involved in the management of a functional team in an operational environment. In the second part of the questionnaire, the respondents were put in a self-assessment situation to reveal their styles of leadership. Forty Likert-scale question ranging from 1 (never) to 5 (always) were designed to explore the managers' leadership attitudes. Each dependent variable was targeted by 20 questions, designed based on the leadership dimensions proposed by Stogdill (1974) [24]. In order to check the reliability of the questionnaire, a pilot test was conducted among a small group of respondents consisting of 20 managers and Cronbach's Alpha was applied as a measure to analyze the collected data. The results revealed that in both variables (concern for tasks and concern for individuals) the designed questions were strongly reliable.

In the main survey, the questionnaire was uploaded on the internet and its link was distributed among some managers across the globe. The professional communities of managers on social networks were broadly used to identify the targeted respondents and distribute the questionnaire among them. Finally, the required data were collected from 159 project managers and 171 operations managers as well. Independent sample t-test was applied to analyze the collected data and do the hypothesis test. Also, Mean value was used as a measure to make a comparison between the two groups of managers.

\section{ANALYSIS AND RESULTS}

From all the managers participated in this survey, $32 \%$ were females and $68 \%$ were males. The mean age of respondents was 37.5 years old and their working experience, was 15 years in average. Most of the respondents (171) were operations managers whereas a minority of them (159) was formed by project managers.

The results of independent sample t-test for both dependent variables are summarized in Table 1. According to the table, in terms of 'concern for individuals' there is a significant difference ( $p>0.05)$ between project managers and operations managers whereas in 'concern for tasks', the difference between the two groups of managers is not statistically significant.

Table1 Independent sample t-test

\begin{tabular}{|c|c|c|c|c|c|c|c|}
\hline & \multicolumn{7}{|c|}{ T-test for Equality of Means } \\
\hline & \multirow[b]{2}{*}{$\mathrm{T}$} & \multirow[b]{2}{*}{ Df } & \multirow{2}{*}{$\begin{array}{c}\text { Sig. } \\
(2- \\
\text { taile } \\
\text { d) }\end{array}$} & \multirow{2}{*}{$\begin{array}{c}\text { Mean } \\
\text { Differenc } \\
\mathrm{e}\end{array}$} & \multirow{2}{*}{$\begin{array}{c}\text { Std. Error } \\
\text { Differenc } \\
\text { e }\end{array}$} & \multicolumn{2}{|c|}{$\begin{array}{l}95 \% \text { Confidence } \\
\text { Interval of the } \\
\text { Difference }\end{array}$} \\
\hline & & & & & & Lower & Upper \\
\hline $\begin{array}{c}\text { Concern for } \\
\text { tasks }\end{array}$ & -1.071 & 328 & .285 & -1.83 & 1.77 & -5.21 & 1.53 \\
\hline $\begin{array}{l}\text { Concern for } \\
\text { individuals }\end{array}$ & 14.749 & 229.98 & .000 & 28.95 & 1.96 & 25.08 & 32.81 \\
\hline
\end{tabular}

Moreover, Table2 illustrates that in 'concern for individuals', the project managers have scored strongly higher than operations managers. On the other hand, in 'concern for tasks' both groups of managers have scored almost equally. 
Table2 Comparison between groups

\begin{tabular}{|c|l|c|c|c|c|}
\hline & $\begin{array}{c}\text { Leadership Style of the } \\
\text { project manager }\end{array}$ & $\mathbf{N}$ & Mean & $\begin{array}{c}\text { Std. } \\
\text { Deviation }\end{array}$ & $\begin{array}{c}\text { Std. Error } \\
\text { Mean }\end{array}$ \\
\hline $\begin{array}{c}\text { Concern for } \\
\text { tasks }\end{array}$ & Project Managers & 159 & 53.64 & 15.46 & 1.22 \\
\hline Operations Managers & 171 & 55.47 & 15.68 & 1.19 \\
\hline individuals & Operations Managers & 171 & 46.45 & 23.59 & .77 \\
\hline
\end{tabular}

As a result, the first hypothesis is rejected whereas the second one is accepted.

\section{DISCUSSION}

The analysis of collected data proved that in comparison with those individuals who are attracted to operations management branches, the enthusiasts of project management are more individual-oriented. Also their 'concern for individuals' is balanced with their 'concern for tasks'; on the other hand, this research proved that among those individuals who are involved in operations management areas, the concerns paid for tasks and individuals are not balanced, because they are mostly task-oriented and pay less attention for individuals. The following figure (Fig.2) summarizes the result of this research.
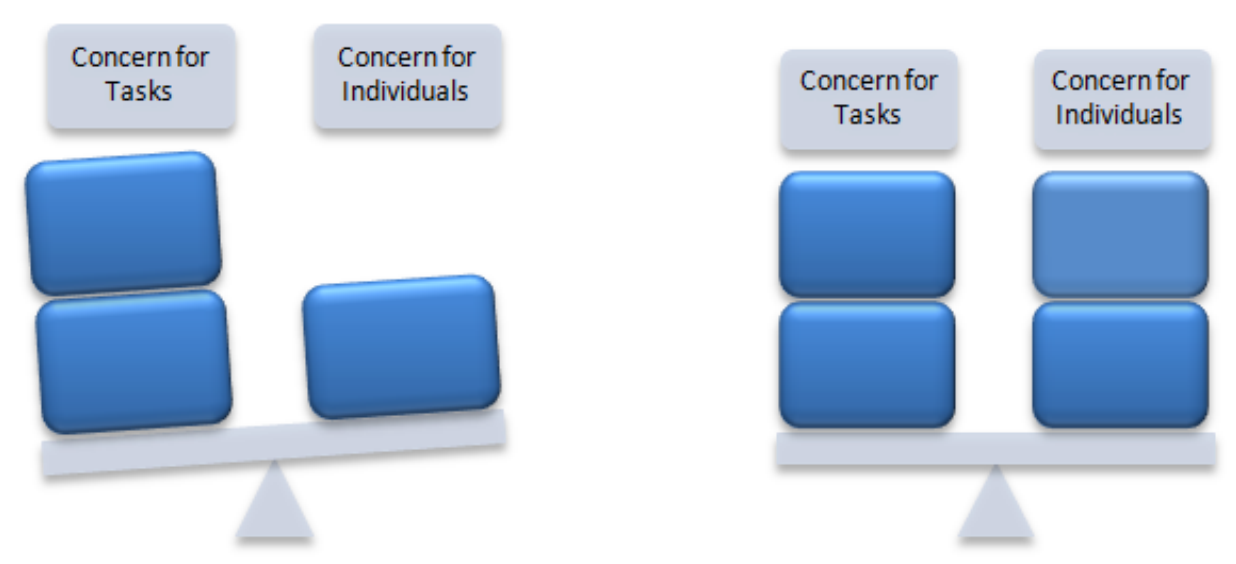

Figure 2 Comparing leadership styles of project managers (right) with operations managers (Left)

The special conditions under which project managers operate underelie their individual-oriented behaviors. Project management is a challenging job with different difficulties and responsibilities compared to the various fields of operations managements. As a result, project managers encounter some challenges and difficulties that are not normally experienced by operations managers. For instance, project managers have to deal with temporary employees who normally have lower degrees of organizational commitment in comparison with permanent employees (Minavand et al, 2013a) [25]. Such employees under any minor pretext may easily leave their jobs and put the project in serious problems. Workload and the stressful conditions of project-based activities aggravates such behaviors among project employees (Kryvenda, 2012)[26]. In such situations, individual-oriented leadership can help a project manager to motivate the employees, elevate their job satisfaction, and minimize the rate of turnover among them (Minavand et al, 2013b) [27].

Anyway, in order to overcome the special conditions of project-based activities, project managers need special abilities and competencies. Researchers have focused on several characteristics and competencies of project managers that distinguish them from operations managers. For example, a study in this area reveals that project managers score better in competencies such as critical analysis, sensitivity, and conscientiousness (Turner et al, 2009) [23]. But several groups of researchers (Makilouko, 2004; Jacque et al, 2007; Minavand et $a l, 2013 a)$ [20] [21] [25] agree on EQ and interpersonal skills as the essential competencies required for a project manager. These competencies can help a project manager to make a proper relationship with employees, exert an effective individual-oriented leadership, and consequently overcome all the complicated challenges of the project.

\section{SUMMARY AND CONCLUSION}

Project management and operations management are the two major types of management in any typical organization. The first one deals with a project as a temporary activity which targets a unique output, and the 
second one is involved in operations as permanent activities with repetitive outputs. The mentioned differences between project and operations naturally results in some differences between project managers and operations managers in terms of leadership styles and competencies. The current study focused on managers' concern for tasks and concern for individuals to make a comparison between the leadership styles of these two groups of managers. Our investigation among a big group of managers in a global context revealed that concern for individuals is significantly higher in the project managers groups, whereas between the two groups, any significant difference was not found in terms of concern for tasks.

As a whole, because of the temporary nature of projects and the special difficulties of workforce management in temporary organizations, the way in which project managers interact with their subordinates is much more complicated in comparison with operations managers. In addition, the importance of achieving the objectives of the project within a limited period of time and using limited resources makes the project managers pay enough attention to tasks and results. Consequently, a manager with the ability to balance between the requirements of the project and the expectations of the subordinates is the essential requirement of any project.

In conclusion, regarding the common challenges along the life cycle of a project, and based on the discussions of the current study, individual-oriented behaviors can effectively help a project manager to overcome the challenges and increase the chance of success for the project. Nevertheless, tasks and results cannot be ignored, and acombination of both styles is the best choice of a project manager.

\section{REFERENCES}

[1] Northouse, P. G.(2010). Leadership: Theory and practice(5th ed.).Thousand Oaks,CA: Sage.

[2] Mullins, L. J.(2000). Management and Organisational Behaviour, Pitrnan Publishers, pp.259.

[3] Bryman, A. (1992). Charisma and leadership in organizations (p. 198). London: Sage.

[4] Bolden, R., Gosling, J., Marturano, A. \& Dennison, P. (2003) A review of leadership theory and competency framework Centre for Leadership Studies, University of Exeter, UK.

[5] Staehle, W. 1999. Management: eine verhaltenswissenschaftliche Perspektive. 8 Auflage. München: Vahlen.

[6] Krumm, D. J. (2001). Leadership. In D. J. Krumm. Psychology at work: An introduction to industrial/organizational psychology (pp.235-278). New York: Worth Publishers.

[7] Yukl, G.A. (2002) Leadership in Organizations: Fifth Edition, Upper Saddle River, NJ, Prentice-Hall.

[8] Zaleznik, A. (1977) Managers and leaders: Are they different? Harvard Business Review, May-June, pp. 67-78. Reproduced in Jeffrey Sonnenfeld (1995) Concepts of Leadership, Aldershot: Dartmouth Publishing Co. Ltd.

[9] Nanus (1985) Leaders: The Strategies for Taking Charge. New York HarperCollns.

[10] Kotter, J. P. (1990). A force for change: How leadership differs from management. Simon and Schuster

[11] Gosling, J., \& Mintzberg, H. (2003). The five minds of a manager. Harvard Business Review, 81(11), 54-63.

[12] Bolden, R. (2004). What is leadership?Unicersity of Exeter, center for leadership studies.

[13] Mintzberg, H. (2004). Managers, not MBAs: A hard look at the soft practice of managing and management development. BerrettKoehler Publishers.

[14] Northouse, P. G. (2011). Introduction to leadership: Concepts and practice. Sage Publications, Incorporated.

[15] Yukl, G. (2009). Leading organizational learning: Reflections on theory and research. The Leadership Quarterly, 20(1), 49-53.

[16] Yukl, G. (2006). Leadership in organizations, Sixth edition. Upper Saddle River, NJ: Prentice Hall.

[17] Prabhakar, G. P. (2008). Projects and their management: A literature review. International Journal of Business and Management, 3 (8), P3.

[18] PMI (Project Management Institute) Standards Committee (1996). A Guide to the Project Management Body of Knowledge (PMBOK® Guide). Upper Darby, PA. Project Management Institute.

[19] Pinto, J., Thoms, P., Trailer, J., Palmer, T., \& Govekar, M. (1998). Project leadership: From theory to practice. Project Management Institute.

[20] Mäkilouko, M. (2004). Coping with multicultural projects: the leadership styles of Finnish project managers. International Journal of Project Management,22(5), 387-396.

[21] Jacques, P. H., Garger, J., \& Thomas, M. (2007). Assessing leader behaviors in project managers. Management Research News, 31(1), 4-11.

[22] Dulewicz, V., \& Higgs, M. (2005). Assessing leadership styles and organisational context. journal of Managerial Psychology, 20(2), $105-123$.

[23] Turner, J. R., Müller, R., \& Dulewicz, V. (2009). Comparing the leadership styles of functional and project managers. International Journal of Managing Projects in Business, 2(2), 198-216.

[24] Stogdill, R. M. (1974). Handbook of leadership: A survey of theory and research. Free Press

[25] Minavand, H., Faharmandian, S., \& Minaei,V.(2013). HR Challenges of Project Managers. IOSR journal of business and management.11(5), 40-45.

[26] Kryvenda, A. (2012). Reducing Adversity of Employee Turnover within Projects. Case Study at Volvo Car Corporation.

[27] Minavand, H., Mokhtari,S.E., Zakerian, H., \& Pahlevan, S..(2013). The impact of project managers' leadership style on employees' job satisfaction, performance and turnover. IOSR journal of business and management.11(6), 43-49. 